\title{
INDUCTION OF POLYPLOIDY IN GIANT MISCANTHUS (MISCANTHUS $\times$ GIGANTEUS GREEF ET DEU.)
}

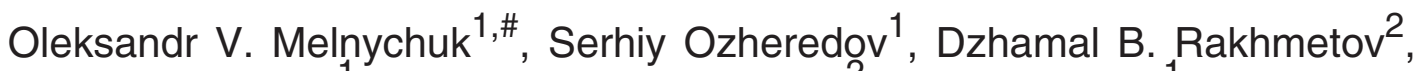 \\ Olena O. Shysha ${ }^{1}$, Svitlana O. Rakhmetova ${ }^{2}$, Alla I. Yemets ${ }^{1}$, \\ and Yaroslav B. Blume ${ }^{1}$

\footnotetext{
${ }^{1}$ Institute of Food Biotechnology and Genomics, National Academy of Sciences of Ukraine, 2a Str., Kyiv, 04123, UKRAINE

${ }^{2}$ M. M. Hryshko National Botanical Garden, National Academy of Sciences of Ukraine, 1 Tymiryazevska Str., Kyiv, 02000, UKRAINE

\# Corresponding author, cellbio@ cellbio.freenet.viaduk.net
}

Communicated by Isaak Rashal

\begin{abstract}
Results of obtaining miscanthus polyploid lines using both classic and new dinitroanilines to improve productivity of biomass as well as quality for biofuel production are represented. All of compounds applied in the study appeared to be able to induce poyploidy in Miscanthus $\times$ giganteus. It was found that new antimitotics have a lower phytotoxicity level compared to classic dinitroanilines. Ploidy level of obtained lines was confirmed by cytological studies using light microscopy. These lines are acclimatised for growing in open soil conditions. Currently, morphometric parameters of selected lines are being studied and analysed.
\end{abstract}

Key words: antimitotic agents, cell culture, dinitroanilines, tubulin binding, polyploidisation.

\section{INTRODUCTION}

Popularity of alternative energy sources and, in particular, the second generation biofuel production technologies, is conditioned by requirement of modern progress in sustainable supply of energy resources (Clifton-Brown et al., 2008). Utilisation of renewable energy sources, such as wind, solar radiation and biomass, is one of the main components of sustainable economic prosperity that has significant environmental and energy results. In addition, cultivation of technical crops to produce biofuels as well as biomass production solve the problem of contaminated lands utilisation as well as lands unsuitable for growing food crops (Tytko and Kalynychenko, 2010).

Giant miscanthus (Miscanthus $\times$ giganteus), belonging to the family Poaceae, is one of the most promising species for biofuel production (Weijde et al., 2017). Representatives of this perennial grass use the $\mathrm{C}_{4}$ photosynthesis pathway, which gives them an advantage of higher utilisation of solar energy and water use efficiency (Weijde et al., 2013). M. × giganteus has high productivity while having low requirements for soil conditions, as it has high drought tolerance and a low level of nitrogen uptake from soil. These features make it one of the best candidates for biofuel production (Somerville et al., 2008). According to published data, dry yield of $M . \times$ giganteus can reach 39.89 t/ha (Bilandzija et al., 2018). However, as an interspecific hybrid between diploid $M$. sinensis $(2 \mathrm{n}=2 \mathrm{x}=38)$ and tetraploid $M$. sacchariflorus $(2 \mathrm{n}=4 \mathrm{x}=76), M . \times$ giganteus $(2 \mathrm{n}=3 \mathrm{x}=57)$ has 57 chromosomes and is a sterile alotriploid (Rayburn et al., 2009; Chramiec-Glabik et al., 2012). In the case of sterile M. $\times$ giganteus, polyploidisation is an indispensable method for obtaining new plant populations and providing genetic diversity. The majority of polyploid plants have an advantage due to larger cell size and plant biomass and, as a result, higher potential yield (Birchler et al., 2003). Polyploidisation methods for obtaining tetraploids, fertile amphidiploids or hexaploids have been successfully applied to miscanthus (Yu et al. 2009; Petersen et al., 2002; Petersen et al., 2003; Glowacka et al., 2010b; Dalton, 2013).

A classic antimitotic agent that has been used to double chromosomes and has been known since the 1930s is colchicine (Blakeslee and Avery, 1937; Thomas, 1993; Yemets and Blume, 2008). Plant material treatment with compounds belonging to dinitroanilines similarly as treatment with colchicine also leads to polyploidisation (Yemets and Blume, 2008). However, affinity of colchicine as well as related compounds to plant tubulin is relatively low (Banerjee et al., 2007; Spasevska et al., 2017), so the use of dinitroanilines as substances to block microtubule polymeri- 
sation, thus blocking the formation of mitotic spindle by these compounds, has become more and more widespread (Yemets and Blume, 2008; Îzheredov et al., 2009). Oryzalin and trifluralin are the most commonly used representatives of dinitroanilines. Mode of action of these compounds is to block the polymerisation of microtubules (Britsun et al., 2009). Results of several researchers suggest that effectiveness of oryzalin is higher than in the case of colchicine for in vitro polyploidisation of $M . \times$ giganteus. At the same time, oryzalin treatment leads to a decrease in number of regenerated polyploids, in comparison to colchicine treatment, which indicates a high level of phytotoxicity of the former (Yu et al., 2009). Similar results were also obtained in studies of polyploidisation in other cereals (Wan et al., 1991). These studies reveal low efficiency of classic dinitroaniline application for obtaining polyploids, which is associated with the high level of their phytotoxicity. Therefore, a promising aspect was screening and application of new dinitroanilines that are significantly less phytotoxic, compared to commonly used representatives of this class of compounds (oryzalin, trifluralin), but are not significantly inferior in their ability of blocking tubulin polymerisation (Îzheredov et al., 2009; Îzheredov et al., 2010). The accumulated knowledge on plant genomics and applying in silico methods allows mass screening of low molecular weight compounds with low phytotoxicity to their affinity to $\alpha$-tubulin of a particular organism, in order to find the most promising compounds for further application in in vitro induction of polyploidy in $M . \times$ giganteus (Melnychuk et al., 2016).

The aim of the work was to develop an effective method of polyploidisation in vitro for Miscanthus genus representatives using promising antimitotic compounds of class dinitroaniline that have low phytotoxicity, to obtain polyploid lines of miscanthus for further application as raw biofuel material for breeding.

\section{MATERIALS AND METHODS}

Plant material. Aseptic $M . \times$ giganteus plants, variety Gulliver, were used in the experiments. Plant material was obtained from the collection of the Department of New Cultures of M. M. Hryshko National Botanical Garden, National Academy of Sciences of Ukraine.

Compounds for polyploidisation. Commercially available dinitroanilines — trifluilarin

(2,6-dinitro- $N, N$-dipropyl-1-4-(trifluoromethyl)aniline, $\mathrm{C}_{13} \mathrm{H}_{16} \mathrm{~N}_{3} \mathrm{~F}_{3} \mathrm{O}_{4}, M-335.5$ ) and oryzalin (4-(Dipropylamino)-3,5-dinitrobenzenesulfonamide, $\mathrm{C}_{12} \mathrm{H}_{18} \mathrm{~N}_{4} \mathrm{O}_{6} \mathrm{~S}, M$ 346.36) were from Fluka (Switzerland). Other promising dinitroanilines used in the experiments (Table 1) were provided by the Institute of Organic Chemistry of the National

Table 1. List of tested newly synthesised antimitotic compounds used for polyploidisation of $M . \times$ giganteus

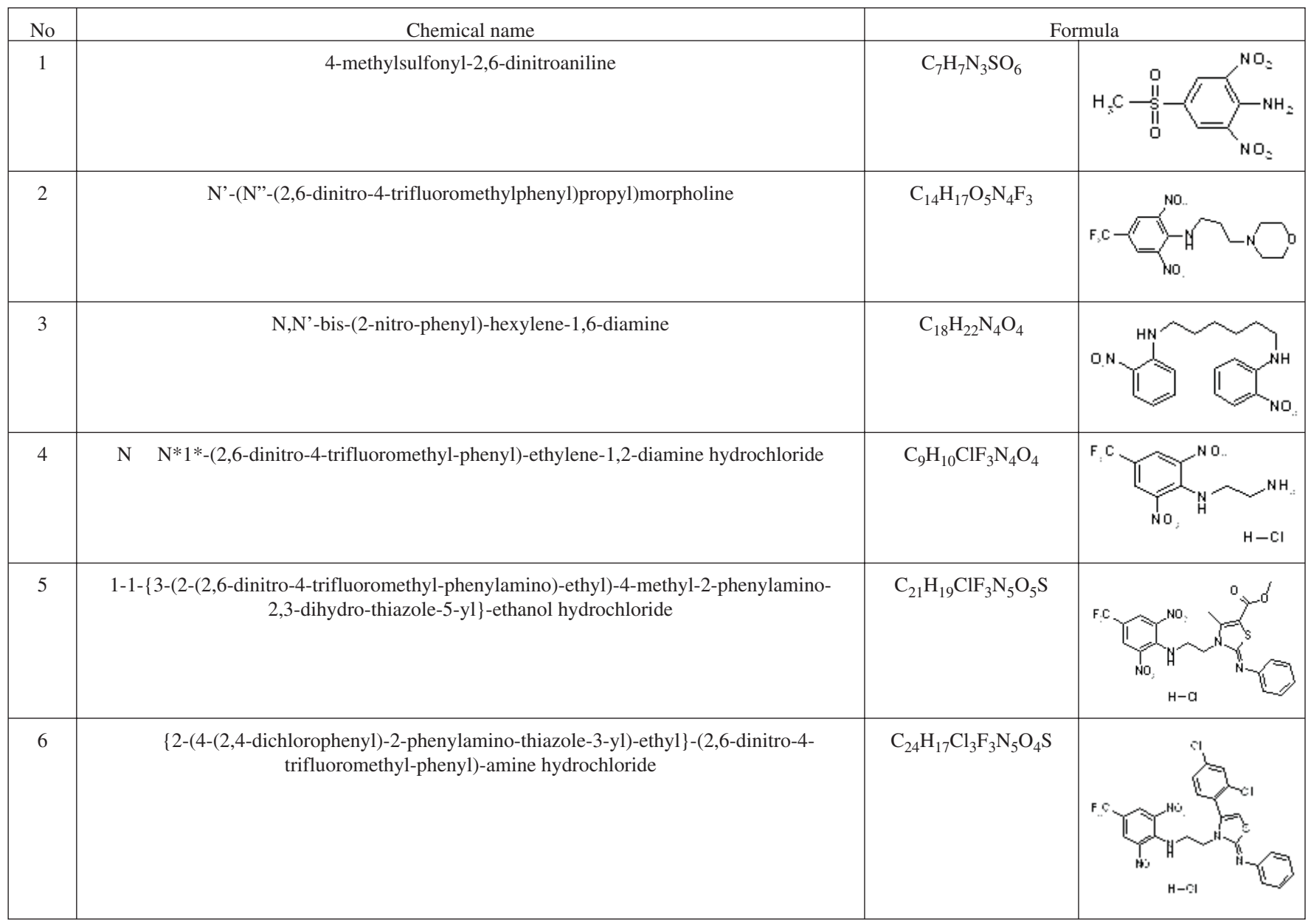


Academy of Sciences of Ukraine. Dinitroaniline derivatives were dissolved in dimethyl sulfoxide (DMSO). Stock solutions were prepared at concentration $10 \mu \mathrm{M}$ and stored at $-20{ }^{\circ} \mathrm{C}$. For the experiments, fresh drug solutions of various concentrations were prepared by dilution of stock solution with distilled water. Total concentration of DMSO in solutions did not exceed 0.5\% (Robinson and Engelborghs, 1982).

In vitro culture establishment. Surface sterilisation of plant material was conducted in aseptic conditions. As explants, root adventitious buds with small fragments of rhizomes were used. Explants were taken from fresh roots that were thoroughly washed from soil. The main criteria for selection of explants were: optimal size of adventitious buds of rhizomes (0.3-1 cm depending on miscanthus type), viability of explants and absence of mechanical damage. The method involved pretreatment of explants with a 3\% solution of sodium hypochlorite for 20 min with subsequent removal of dead tissues, rhizomes fragments and washing with sterile water. The pretreated material was sterilised in a $0.08 \%$ solution of silver nitrate $\left(\mathrm{AgNO}_{3}\right)$ for $20 \mathrm{~min}$. with subsequent washing with sterile distilled water (Melnychuk et al., 2015). After surface sterilisation explants were cultured on a solid MC medium (Murashige and Skoog, 1962) and supplemented with $30 \mathrm{~g} / \mathrm{l}$ sucrose as a carbon source. The medium was supplemented with $50 \mathrm{mg} / \mathrm{l}$ cysteine to reduce phenolic compounds accumulation. All other variants of media used in the experiments also contained cysteine (Gubisova et al., 2013). Cultivation conditions were: 16/8 h photoperiod and temperature $24{ }^{\circ} \mathrm{C}$.

Micropropagation through direct morphogenesis. Solid medium MC was used to obtain a sufficient number of in vitro shoots by micropropagation. 6-benzyl aminopurine (BAP) in the amount of $2 \mathrm{mg} / \mathrm{l}$ was added to the medium to enhance formation of adventitious buds, shoot formation and shoot growth. Cultivation conditions were: $16 / 8 \mathrm{~h}$ photoperiod and temperature $24{ }^{\circ} \mathrm{C}$.

Micropropagation through indirect morphogenesis. Induction of callusogenesis was conducted by cultivating shoots in vitro on solid MC medium, using $30 \mathrm{~g} / \mathrm{l}$ sucrose as a carbon source. With the aim to determine the most effective ratio of auxins and cytokinins for callusogenesis, BAP (0.05 mg/l, $0.1 \mathrm{mg} / \mathrm{l}, 0.2 \mathrm{mg} / \mathrm{l})$ and 2,4-dichlorophenoxyacetic acid (2.4 D) $(2.5 \mathrm{mg} / \mathrm{l}, 5 \mathrm{mg} / \mathrm{l})$ were added to nutrition media at various proportions. Adventitious buds from rhizomes and shoots in vitro obtained by micropropagation were used as explants. Cultivation was carried out in Petri dishes containing $30 \mathrm{ml}$ medium. Explants $50-100 \mathrm{~mm}$ in length were placed without immersion in the medium, 5 per dish. Explants were cultured at $24{ }^{\circ} \mathrm{C}$ in the dark. Every 14 days, explants were transferred to fresh medium with an appropriate combination of growth regulators. For plantlet regeneration from callus, the explants were transferred to solid medium MC with addition of $2 \mathrm{mg} / \mathrm{l} \mathrm{BAP}$. As a carbon source $30 \mathrm{~g} / \mathrm{l}$ sucrose was used. Cultivation conditions were: $16 / 8 \mathrm{~h}$ photoperiod and temperature $24{ }^{\circ} \mathrm{C}$.
Polyploidisation in vitro. Polyploidisation of $M . \times$ giganteus was induced in two ways:

- Regeneration of plants from callus culture on media supplemented with antimitotic agents at various concentrations $(3.5$ and $10 \mu \mathrm{M})$ for 7 and 14 days with subsequent transfer to media free of antimitotic agents. Cultivation conditions were: $16 / 8 \mathrm{~h}$ photoperiod and temperature $24{ }^{\circ} \mathrm{C}$.

- Cultivation of shoots in vitro was on micropropagation media supplemented with antimitotic agents at various concentrations $(3,5,10,25$ and $50 \mu \mathrm{M})$ for 7 and 14 days, followed by transfer to medium free of antimitotics. Cultivation conditions were: $16 / 8 \mathrm{~h}$ photoperiod and temperature $24{ }^{\circ} \mathrm{C}$.

Rooting, potting and transplanting to soil of obtaining lines. Rooting of obtained lines was conducted on solid MC medium with addition of $1 \mathrm{mg} / \mathrm{l} 1$-naphthaleneacetic acid (NAA). Cultivation conditions were: $16 / 8 \mathrm{~h}$ photoperiod and temperature $24{ }^{\circ} \mathrm{C}$ (Gubisova et al., 2013). After three weeks of cultivation, 3-10 well-developed roots appeared on the basal part of the shoots. Rooted shoots were washed under tap water to remove residues of medium and planted in cassettes for seedlings ( 77 cells), $45 \times 45 \times 62 \mathrm{~mm}$ in size, filled with a universal substrate for seedlings, which included peat, 1-6 $\mathrm{mm}$ in size, sand, perlite and microelements ( $\mathrm{Fe}, \mathrm{Mn}, \mathrm{B}, \mathrm{Cu}, \mathrm{Zn}, \mathrm{Mo})$, pH 5,5-6,5. Planted individuals in soil were cultivated at temperature $18-25^{\circ} \mathrm{C}$ with regular watering of the substrate.

Ploidy level determination. Determination of the ploidy level of obtained lines was carried out by counting chromosome number in root tips apical meristem. Material for microscopy was fixed for $18 \mathrm{~h}$ at $18-20{ }^{\circ} \mathrm{C}$ in Clark solution (96\% ethanol and acetic acid, $3: 1)$ and washed in $70 \%$ ethanol (Kundelchuk et al., 2002). Specimens were macerated in $1 \mathrm{~N} \mathrm{HCl}$ and stained with $1 \%$ carmine in $45 \%$ acetic acid. Temporary specimens were prepared by squashing in a drop of $45 \%$ lactic acid (Pausheva, 1988). Chromosome counting was performed using a microscope Zeiss, Axioscop 40. Results were documented using a digital camera Zeiss, Axiocam MRC 5 and software Axivision Rel. 4.7.

\section{RESULTS}

In our experiments different methods of plant material treatments with dinitroanilines were studied to determine the most efficient method for polyploidisation. Cultivation of callus was conducted on regeneration media supplemented with antimitotic compounds of various concentrations (3-10 $\mu \mathrm{M})$ and of aseptic shoots on media for micropropagation with addition of antimitotic compounds in different concentrations $(3-50 \mu \mathrm{M})$ with durations 7 and 14 days, followed by transfer to free of antimitotic compounds media.

To determine optimal combination of growth regulators for induction of callusogenesis in $M . \times$ giganteus, six different combinations of auxins and cytokinins were tested (Ta- 
Table 2. Influence of growth regulators combinations on callusogenesis of $M . \times$ giganteus (the $30^{\text {th }}$ day)

\begin{tabular}{|c|c|c|c|c|c|}
\hline & $\begin{array}{l}\text { Growth } \\
\text { regulator }\end{array}$ & $\begin{array}{c}\text { Concentration, } \\
\mathrm{mg} / \mathrm{l}\end{array}$ & $\begin{array}{c}\text { Survived, } \\
\%\end{array}$ & $\begin{array}{c}\text { Explants with } \\
\text { embryogenic } \\
\text { and shoot } \\
\text { forming } \\
\text { callus, \% }\end{array}$ & $\begin{array}{c}\text { Explants with } \\
\text { dark, unviable } \\
\text { callus, } \%\end{array}$ \\
\hline \multirow[t]{2}{*}{1} & BAP & 0.05 & \multirow{2}{*}{82.1} & \multirow{2}{*}{12.5} & \multirow{2}{*}{29.7} \\
\hline & $2,4-\mathrm{D}$ & 2.5 & & & \\
\hline \multirow[t]{2}{*}{2} & BAP & 0.1 & \multirow{2}{*}{86.7} & \multirow{2}{*}{6.0} & \multirow{2}{*}{32.0} \\
\hline & $2,4-\mathrm{D}$ & 2.5 & & & \\
\hline \multirow[t]{2}{*}{3} & BAP & 0.2 & \multirow{2}{*}{85.9} & \multirow{2}{*}{8.1} & \multirow{2}{*}{31.2} \\
\hline & 2,4-D & 2.5 & & & \\
\hline \multirow[t]{2}{*}{4} & BAP & 0.05 & \multirow{2}{*}{92.2} & \multirow{2}{*}{34.6} & \multirow{2}{*}{27.2} \\
\hline & $2,4-\mathrm{D}$ & 5.0 & & & \\
\hline \multirow[t]{2}{*}{5} & BAP & 0.1 & \multirow{2}{*}{87.7} & \multirow{2}{*}{61.6} & \multirow{2}{*}{34.8} \\
\hline & 2,4-D & 5.0 & & & \\
\hline \multirow[t]{2}{*}{6} & BAP & 0.2 & \multirow{2}{*}{92.7} & \multirow{2}{*}{31.4} & \multirow{2}{*}{48.3} \\
\hline & $2,4-\mathrm{D}$ & 5.0 & & & \\
\hline
\end{tabular}

ble 2). The resulting callus culture was assessed on the $30^{\text {th }}$ day of cultivation. Number of explants with induced callus culture was determined. Obtained calli were estimated by colour and structure. Callus was evaluated visually distinguishing four types: white embryogenic callus; shoot-forming callus, in good condition; dark or yellow callus; dark brown, the last two are not viable callus types. According to the results of the study, the highest number of embryogenic callus and shoot-forming callus were induced on medium supplemented with $2,4 \mathrm{D}-5 \mathrm{mg} / \mathrm{l}$ and BAP $-0.1 \mathrm{mg} / \mathrm{l}$ (Table 2). Similar results were obtained for both types of explants: adventitious buds from rhizomes and shoots in vitro obtained by micropropagation (Fig. 1).

After 16-18 days of cultivation, the first dedifferentiated tissue started to appear on explants, and after two months of cultivation, explants were completely covered with callus with a large number of embryo-like structures. The obtained callus was used for further regeneration and polyploidisation in vitro on solid MS medium with addition of dinitroanilines. Table 3 shows the results of plant regenera- tion from callus on media with oryzalin and trifluralin. Concentrations of antimitotic drugs in the range of 3-10 $\mu \mathrm{M}$ resulted in significant reduction in survival of callus and, especially, in number of regenerated plants. Thus, after callus cultivation on medium with oryzalin, survival rates of explants were 6.7-20\%, respectively. Callus cultivation on medium with trifluralin resulted in a 9.3-33.3\% survival rate of explants (Table 3).

Solid medium MS was used to inducing polyploidy by cultivation in vitro shoots. Shoots were cultured on media with dinitroanilines for 7 and 14 days, and then the shoots were transferred to test tubes with fresh medium free of antimitotic drugs (Fig. 2). Number of survived shoots was counted on the $30^{\mathrm{th}}$ day after beginning of cultivation. The obtained new shoots were counted, divided into separate lines and micropropagated. Subsequently, ploidy level of these lines was determined. Survival rates of in vitro shoots on media with dinitroanilines are presented in Table 4. Oryzalin and trifluralin had higher level of phytotoxicity compared to newly tested dinitroanilines. After in vitro shoot cultivation for 7 days on medium with oryzalin and trifluralin in concentration $10 \mu \mathrm{M}$, the survival rate of explants was 44.9 and $74.5 \%$, respectively, and after increase of concentration up to $50 \mu \mathrm{M}$ the survival rate was only 16.6 and $8.3 \%$. At the same time, when new dinitroanilines were used in concentration $10 \mu \mathrm{M}$, survival rate of explants was $96.0-98.8 \%$, and when the concentration increased up to $50 \mu \mathrm{M}$ the rate was $83.3-91.6 \%$ (Table 4). Similar results were obtained after 14 days of cultivation on media with classic dinitroanilines. After in vitro shoot cultivation for 14 days on media supplemented with $10 \mu \mathrm{M}$ of oryzalin and trifluralin, survival rates of explants were 21 and $54 \%$, respectively, and after increase of concentration up to $50 \mu \mathrm{M}$, survival rate of explants was $8.3 \%$ for both. Newly tested dinitroanilines in concentration $10 \mu \mathrm{M}$ showed a survival rate of explants within the range of 95.3-98.0\% and at $50 \mu \mathrm{M}-83.3-91.6 \%$ (Table 5). Therefore, application of new dinitroanilines is more effective to produce polyploid plants of $M . \times$ giganteus .
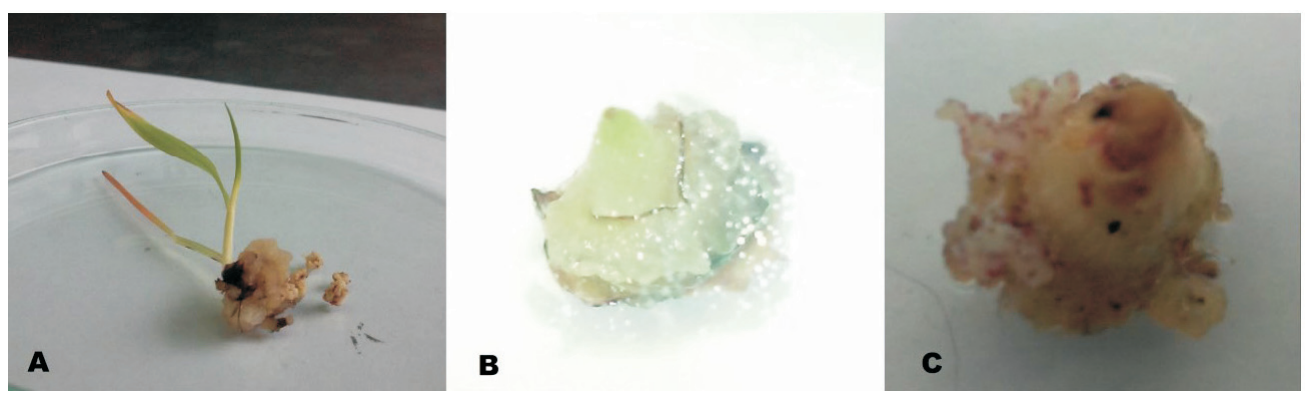

Fig. 1. Callusogenesis induced from in vitro shoots $(\mathrm{A})$ and buds $(\mathrm{B}, \mathrm{C})$ of M. $\times$ giganteus.

Table 3. Regeneration of M. $\times$ giganteus from callus on media with antimitotic compounds (first 7 days) on the 30 th day of cultivation

\begin{tabular}{|c|c|c|c|c|c|c|}
\hline \multirow{3}{*}{ Agent } & \multicolumn{6}{|c|}{ Concentration, $\mu \mathrm{M}$} \\
\hline & \multicolumn{2}{|c|}{3.0} & \multicolumn{2}{|c|}{5.0} & \multicolumn{2}{|c|}{10.0} \\
\hline & regenerated, $\%$ & survived, $\%$ & regenerated, $\%$ & survived, $\%$ & survived, $\%$ & survived, $\%$ \\
\hline Oryzalin & 22.6 & 20.0 & 22.7 & 11.0 & 23.3 & 6.7 \\
\hline
\end{tabular}




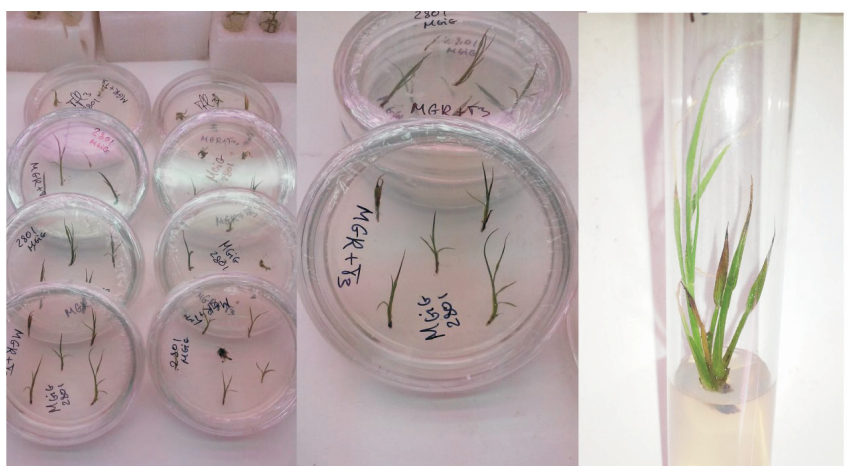

Fig. 2. In vitro cultivation of $M . \times$ giganteus shoots on media with antimitotics agents.

Table 4. Survival of $M . \times$ giganteus explants after 7 days of cultivation on media with dinitroanilines (30 days)

\begin{tabular}{l|cccccc}
\hline \multirow{2}{*}{ Agent } & \multicolumn{5}{c}{ Concentration, $\mu \mathrm{M}$} \\
\cline { 2 - 6 } & 3 & 5 & 10 & 25 & 50 \\
\hline Trifluralin & 90.4 & 88.0 & 74.5 & 27.3 & 8.3 \\
Oryzalin & 89.0 & 85.7 & 44.9 & 25.0 & 16.6 \\
\#1from Tab. 1 & 97.0 & 98.4 & 96.0 & 91.6 & 91.6 \\
\#2 from Tab. 1 & 98.8 & 98.6 & 98.0 & 91.6 & 83.3 \\
\#3 from Tab. 1 & 98.8 & 98.8 & 98.8 & 91.6 & 91.6 \\
\#4 from Tab. 1 & 98.5 & 96.8 & 96.4 & 91.6 & 85.7 \\
\#5 from Tab. 1 & 98.8 & 96.6 & 97.5 & 90.9 & 90.0 \\
\#6 from Tab. 1 & 98.8 & 98.5 & 97.0 & 91.6 & 90.9 \\
$\quad$ Control & 100.0 & 100.0 & 100.0 & 100.0 & 100.0
\end{tabular}

Table 5. Survival of $M . \times$ giganteus explants after 14 days of cultivation on media with dinitroanilines (30 days)

\begin{tabular}{l|c|c|c|c|c}
\hline \multirow{2}{*}{ Agent } & \multicolumn{5}{c}{ Concentration, $\mu \mathrm{M}$} \\
\cline { 2 - 6 } & 3 & 5 & 10 & 25 & 50 \\
\hline Trifluralin & 88.0 & 68.5 & 54.0 & 16.6 & 8.3 \\
Oryzalin & 84.0 & 76.0 & 21.0 & 16.6 & 8.3 \\
\#1from Tab. 1 & 97.1 & 96.7 & 95.3 & 91.6 & 91.6 \\
\#2 from Tab. 1 & 98.8 & 98.0 & 97.6 & 90.9 & 83.3 \\
\#3 from Tab. 1 & 98.8 & 98.8 & 98.0 & 84.6 & 85.7 \\
\#4 from Tab. 1 & 97.0 & 97.0 & 96.4 & 91.6 & 85.3 \\
\#5 from Tab. 1 & 98.0 & 96.8 & 97.4 & 90.0 & 90.0 \\
\#6 from Tab. 1 & 98.0 & 97.6 & 97.2 & 90.9 & 83.3 \\
\multicolumn{1}{c}{ Control } & 100.0 & 100.0 & 100.0 & 100.0 & 100.0
\end{tabular}

Full plant regeneration obtained lines were transferred onto rooting medium and cultivated for 30 days. Plants with well developed root systems were transplanted under aseptic conditions for further acclimatisation and adaptation to open soil conditions (Figs. 3, 4) In order to determine ploidy level of the resulting lines separate roots were used for microscopic studies. Determination of ploidy level of obtained lines was carried out by counting of chromosome number in the apical meristem from root tips. As a result, lines with changed ploidity were obtained (Fig. 5). All substances used in the experiments proved to be able to induce polyploidy in $M . \times$ giganteus.

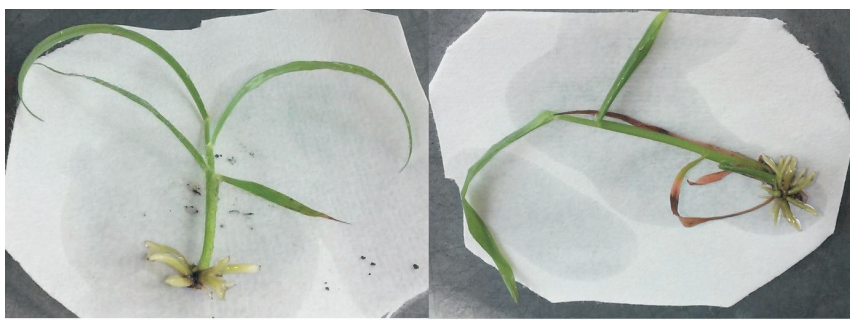

Fig. 3. Rooting of obtained lines $M . \times$ giganteus.

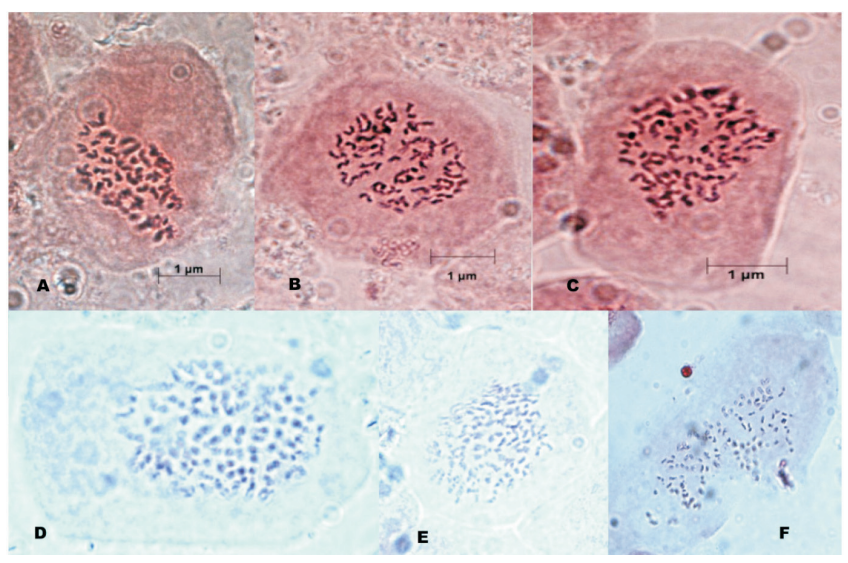

Fig. 4. Chromosome number in of $M . \times$ giganteus root apical meristematic cells:

A, control, 57 chromosomes; B, C, lines with 76 chromosomes; D, E, F, lines with 114 chromosomes.

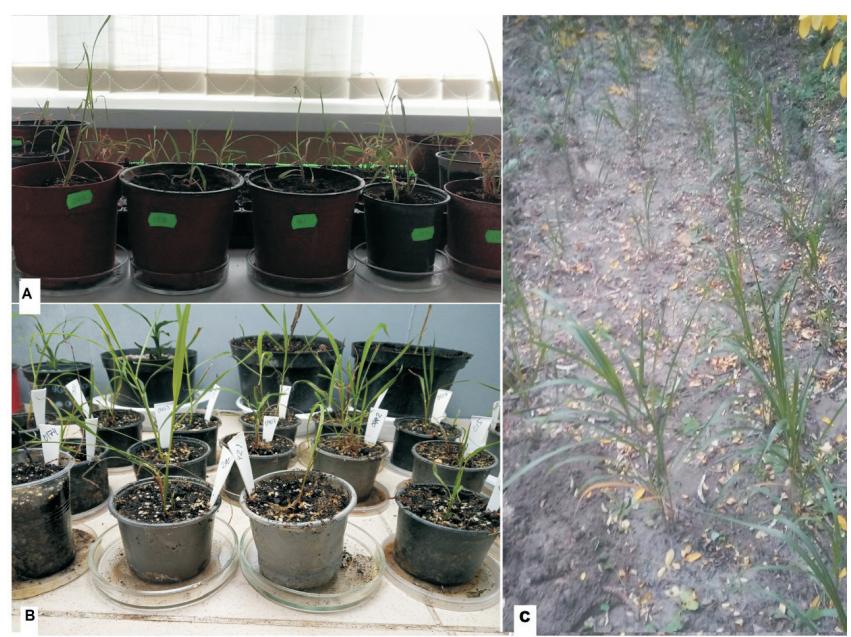

Fig. 5. Polyploid $M . \times$ giganteus lines transplanted in soil: A, B, in pots; $\mathrm{C}$, in open soil conditions.

Currently, analysis of selected $M . \times$ giganteus lines with changed ploidy level and study of their morphometric parameters is ongoing.

\section{DISCUSSION}

Today questions on induction of callusogenesis and plant regeneration from callus $M . \times$ giganteus are well studied (Petersen et al., 2003; Plazek and Dubert, 2010; Wang et al., 2011; Zhang et al., 2012). There are many published results of callus induction from various types of explants, like shoot apexes, immature inflorescences, primordia and frag- 
ments of leaves. Despite seasonality, immature inflorescences are most often used for callus induction. The main advantage of this type of explants is that it is possible to obtain more than 200 explants from one immature inflorescence. In addition, there is a low percentage of explant contamination during in vitro culture establishment compared to other types of explants (Lewandowski, 1997). For induction of callusogenesis in maize, as well as in most cereals, immature embryo proved to be the best explant (Armstrong et al., 1985; Rhodes et al., 1986). Explant type plays an important role in the induction of morphogenic callus for different types of callus. Apex shoots for callusogenesis induction is considered to be less productive compared to use of immature inflorescences, but better in comparison with leaf fragments (Dalton, 2013). Moreover, several researchers indicated that smaller inflorescences produce more embryogenetic and shoot forming types of callus than other types (Holme and Petersen, 1996; Glowacka et al., 2010a; Gubisova et al., 2013). Mature seed is good explant for in vitro culture establishment and allows to obtain a sufficient amount of callus. Wang et al. (2011) successfully induced callus from seeds on MS medium supplemented with relatively high concentration $(5 \mathrm{mg} / \mathrm{l})$ of 2,4-D and a relatively low $(0.01 \mathrm{mg} / \mathrm{l}) \mathrm{BA}$. This ratio of growth regulators allowed to obtain the highest percentage of compact callus $(22.9 \%)$ compared with other variants (Wang et al., 2011). However, this method can not be used to induce callusogenesis in $M$. $\times$ giganteus as a result of sterility of its seeds.

According to published data, in the case of callusogenesis induction from M. sachariflorus shoot apexes, $90 \%$ of induced callus were of embryogenic type, whereas when lateral buds were used - only $31 \%$. However, when shoot apexes of $M . \times$ giganteus were used as explants, only $17 \%$ of explants induced callus, and in the case of lateral buds only $10 \%$ (Dalton et al., 1999). Inducing of callusogenesis from large shoot tips of $M . \times$ giganteus $(6-9 \mathrm{~cm}$ in length) resulted in appearance of morphogenic callus on $100 \%$ explants (Christian and Haase, 2001). It is well known that when rhizome fragments from soil and large shoot tips are used for in vitro culture establishment, a significant proportion of explants remains contaminated, which is the main obstacle for use of underground parts of miscanthus as explants (Lewandowski, 1997). Earlier we have reported about development of in vitro culture methods for $M . \times g i$ ganteus, which allowed use of rhizomes and large shoot tips for induction of callusogenesis (Melnychuk et al., 2015).

It has been reported that $2-3 \mathrm{mg} / 1$ 2,4-D is sufficient for effective induction of embryogenetic callus from miscanthus explants (Christian and Haase, 2001; Zili et al., 2004; Dalton, 2013). Moreover, a low concentration of auxins allows minimisation of somaclonal variations and does not affect further plant regeneration (Plazek et al., 2007). According to the results of our study, the highest percent of white embryogenic and shoot forming callus types was observed on medium supplemented with 5 mg/l 2,4-D. Reducing 2,4-D concentration in nutrition medium caused a decrease in efficiency of calusogenesis and appearance of white embryo- genic and shoot forming callus types were observed only on $8.1 \%$ of explants (Table 2). Similar results of induction of callusogenesis from $M . \times$ giganteus explants with addition to nutrition medium $5 \mathrm{mg} / \mathrm{l}$ of 2,4-D have been published by other authors (Holme and Petersen, 1996; Petersen, 1997). To induce calusogenesis in $M . \times$ giganteus, $0.1-2 \mathrm{mg} / \mathrm{l}$ BAP can be added to the medium. However, some miscanthus genotypes do not seem prone to dedifferentiate if BAP concentrations are higher than $0.01 \mathrm{mg} / \mathrm{l}$ (Dalton, 2013). According to our results, $0.1 \mathrm{mg} / \mathrm{l} \mathrm{BAP}$ concentration appeared to be the most effective for obtaining white embryogenetic and shoot forming callus. Increase in concentration of BAP up to $0.2 \mathrm{mg} / \mathrm{l}$ caused formation of wilted, darkyellow, nonviable callus at high per cent (48.3\%), which was significantly higher than in the case of variant with 0.1 $\mathrm{mg} / \mathrm{l} \mathrm{BAP}$, for which this parameter was $34.8 \%$ (Table 2).

For plant regeneration from callus, media supplemented with different combinations of growth regulators can be used. Most often for this purpose nutrition media based on MS with NAA or 2,4-D in combination with BAP or kinetin are applied (Holme and Petersen, 1996; Holme et al., 1997; Zili et al., 2004; Glowacka and Jezowski, 2009; Yu et al., 2009; Zhang et al., 2012). In our work, for plant regeneration from callus, as well as for micropropagation, media with $2 \mathrm{mg} / \mathrm{l}$ BAP were used. This amount of cytokinins provided best results. According to results of other researchers, effective shoot growth takes place on medium that contains 2-2.5 mg/l BAP (Petersen et al., 2003; Glowacka et al., 2010a). In vitro shoot cultivation on medium with $1-2 \mathrm{mg} / \mathrm{l}$ BAP leads to poor growth and reduction of plant viability in subsequent subcultures (Dalton, 2013).

Antimitotic compounds that block microtubule polymerisation and, consequently, formation of mitotic spindle, are able to induce polyploidy. The most commonly utilised are colchicine, oryzalin and trifluralin. At present, there is a significant number of publications on use of colchicine and oryzalin for in vitro polyploidisation of various miscanthus species (Petersen et al., 2002; Petersen et al., 2003; Yu et al., 2009; Glowacka and Jezowski, 2009; Glowacka et al., 2010b). After cultivation on liquid medium using both colchicine $(939 \mu \mathrm{M})$ and oryzalin $(10 \mu \mathrm{M}), 67 \%$ of callus resulted in polyploids. The best results were obtained on liquid medium with $3.4 \mu \mathrm{M}$ oryzalin and 4-day of cultivation of calli. Oryzalin appeared to be more effective than colchicine for polyploidy induction, but percentage of regenerated plants was lower than in the latter, $8.9 \%$ and $6 \%$, respectively (Yu et al., 2009).

Derivatives of dinitroanilines, like oryzalin and trifluralin, have previously been applied as pre-germination herbicides to suppress root system development by blocking microtubule polymerisation (Britsun et al., 2009). Their advantage is that they are less toxic than colchicine. In spite of a high level of conservativity of tubulins of different origins, dinitroanilines have high affinity to plant tubulin (Morejohn and Fosket, 1991; Yemets and Blume,1999) and weakly interact with fungal and animal tubulins (Banerjee et al., 2007; Spasevska et al., 2017). However, there is a problem 
in application of most known dinitroanilines for inducing polyploidy, due to a high level of phytotoxicity. Numerous studies pointed out high efficiency as well as significant phytotoxicity of trifluralin and oryzalin in polyploidisation of both monocotyledonous and dicotyledonous plants. The high toxicity of both oryzalin and trifluralin was observed in polyploidisation of catnip (Nepeta sp. L.), where shoots were cultured on nutrient medium with dinitroanilines. Phytotoxic effect of both dinitroanilines on growth and development of explants was equally high (Zilbervarg et al., 1997). The results of our studies on polyploidisation with oryzalin are in accordance with previously reported results, highlighting phytotoxicity of this compound. After callus cultivation on solid medium containing $10 \mu \mathrm{M}$ oryzalin, the survival rate of explants did not exceed $6.7 \%$ and only $20.0 \%$ of them were able to regenerate as green plants (Table 3). Similar results were also obtained after cultivation of in vitro shoots for 14 days on media with $50 \mu \mathrm{M}$ oryzalin and trifluralin. Survival rate of explants for both compounds was only $8.3 \%$ (Table 5).

Previously, in order to determine the phytotoxicity level and affinity to plant tubulins of more than 100 newly synthesised derivatives of dinitroaniline, a series of experiments were conducted by our group (Ozheredov et al., 2009; Ozheredov et al., 2010). Testing with Allium showed that phytotoxic effect of typical dinitroaniline compounds (trifluralin) appeared even at concentration $1 \mu \mathrm{M}$. Increase in concentration up to $10 \mu \mathrm{M}$ was accompanied by significant increase in phytotoxicity and at concentration $100-1000 \mu \mathrm{M}$, partial or complete loss of experimental material was recorded. In our study on polyploidy induction of $M . \times$ giganteus, we used a concentration range of 3 to 50 $\mu \mathrm{M}$, as the most potentially effective. Among the previously selected dinitroanilines, we conducted several studies using in silico methods for screening of compounds with high affinity to miscanthus $\alpha$-tubulin and low phytotoxicity (Melnychuk et al., 2016). The list of selected antimitotic substances used in this research is presented in Table 1.

Compounds selected in silico search showed significant reduction in phytotoxicity level compared to variants with trifluralin and oryzalin, which had a positive effect on the survival rate of treated explants. It should be noted that the survival rate of explants in treatments with newly synthesised dinitroanilines varied from $83.3 \%$ to $91.6 \%$, which is significantly higher than in the case of such compounds like oryzalin and trifluralin (Table 5). Lines obtained after treatment with antimitotic compounds were cultured on rooting medium and after development of a root system the plants were potted and adapted to in vivo conditions with following planting in open soil. In vitro rooting of $M . \times$ giganteus effectively occurs on solid MC medium with $1 \mathrm{mg} / \mathrm{l}$ NAA (Gubisova et al., 2013). Obtained roots with active growth were used to prepare squashed specimens in order to determine ploidy level of the lines by light microscopy methods. Currently, about 40 lines of $M$. × giganteus of changed ploidy level have been selected. The analysis of obtained material is still ongoing. Selected promising lines are being acclimatised and planted in open soil conditions, where they are being analysed.

\section{CONCLUSIONS}

Effectiveness of new promising antimitotic compounds belonging to dinitroanilines with low phytotoxicity for polyploidisation of genus Miscanthus were studied. All compounds used in the work proved to be able to induce polyploidy in $M . \times$ giganteus. The most effective was their utilisation in concentrations ranging $10-50 \mu \mathrm{M}$. As a result of culturing in vitro shoots on media supplemented with new dinitroanilines, 27 hexaploid lines of $M . \times$ giganteus with 114 chromosomes were obtained. Selected lines were adapted to growth in open soil conditions. Currently, their biological and economic analysis is underway. Analysis of selected lines and study of their morphometric parameters are ongoing.

\section{ACKNOWLEDGEMENTS}

The work was carried out within the framework of scientific projects "Creation of new high-yielding lines of Miscanthus as a raw materials for bioethanol via obtaining of polyploids" (0113U004719) of R\&D Programme of the National Academy of Sciences of Ukraine "Biological Resources and New Technologies of Bioconversion” (20132117) and "Development of high-yielding polyploid lines of Miscanthus as a raw materials for bioethanol production and characterisation of their productivity" (0118U005354) of $R \& D$ Programme of the National Academy of Sciences of Ukraine "Biofuels and Bioenergy" (2018-2022).

\section{REFERENCES}

Armstrong, C. L., Green, C. E., Phillips, R. L., Stucker, R. E. (1985). Genetic control of plant regeneration from maize tissue cultures. Maize Genet. Cooperation Newslett., 92-93.

Banerjee, M., Roy, D., Bhattacharyya, B., Basu, G. (2007). Differential colchicine-binding across eukaryotic families: The role of highly conserved Pro268b and Ala248b residues in animal tubulin. FEBS Lett., 581, 5019-5023.

Birchler, J. A., Auger, D. L., Riddle, N. C. (2003). In search of the molecular basis of heterosis. Plant Cell., 15, 2236-2239.

Bilandzija, N., Vocan, N., Leto, J., Jurisic, V., Grubor, M., Matin, A., Gersic, A., Krisca, T. (2018). Yield and biomass composition of Miscanthus $x$ giganteus in the mountain area of Croatia. J. Transactions FAMENA, 42, $51-60$.

Blakeslee, A., Avery, G. (1937). Methods of inducing doubling of chromosomes in plants, J. Heredity, 28, 393-411.

Britsun, V. M., Yemets, A. I., Lozinskii, M. O., Blume, Ya. B. (2009). 2,6-Dinitroanilines: synthesis, herbicidal and antiprotozoan properties. Ukr. Bioorg. Acta, 1, 16-27 (in Ukrainian)

Chramiec-Glabik, A., Grabowska-Joashimiak, A., Sliwinska, E., Legutko, J., Kula, A. (2012). Cytogenetic analysis of Miscanthus $\times$ giganteus and its parent forms. Caryologia, 65, 234-242.

Christian, D. G., Haase, E. (2001). Agronomy of Miscanthus. In: Miscanthus for Energy and Fibre. James \&James, London, pp. 21-45. 
Clifton-Brown, J., Chiang, Y. C., Hodkinson, T. R. (eds.) (2008). Miscanthus: Genetic resources and breeding potential to enhance bioenergy production. In: Aspects of Applied Biology. Biomass and Energy Crops. Association of Applied Biologists, Warwick, University of York, UK., pp. 273-294.

Dalton S. J. (2013). Biotechnology of Miscanthus. In: Biotechnology of Neglected and Underutilized Crops. Springer Science Business Media, Dordrecht, pp. 243-294.

Dalton, S. J., Bettany, A. J., Timms, E., Morris, P. (1999). Co-transformed, diploid Lolium perenne (perennial ryegrass), Lolium multiflorum (Italian ryegrass) and Lolium temulentum (darnel) plants produced by microprojectile bombardment. Plant Cell Rep., 18, 721-726.

Glowacka, K., Jezowski, S. (2009). Genetic and nongenetic factors influencing callus induction in Miscanthus sinensis (Anderss.) anther cultures. $J$. Appl. Genet., 50, 341-345.

Glowacka, K., Jezowski, S., Kaczmarek, Z., (2010a). The effects of genotype, inflorescence developmental stage and induction medium on callus induction and plant regeneration in two Miscanthus species. Plant Cell, Tiss. Org. Cult., 102, 79-86.

Głowacka K., Jeżowski S., Kaczmarek Z. (2010b). In vitro induction of polyploidy by colchicine treatment of shoots and preliminary characterisation of induced polyploids in two Miscanthus species. Indust. Crops Prod., 32 (2), 88-96.

Gubisova, M., Gubis, J., Zofajova, A., Mihalik, D., Kraic, J. (2013). Enhanced in vitro propagation of Miscanthus $\times$ giganteus. Indust. Crop Prod., 41, 279-282.

Holme, I. B., Petersen, K. K. (1996). Callus induction and plant regeneration from different explants types of Miscanthus $\times$ ogiformis Honda 'Giganteus'. Plant Cell Tiss. Org. Cult., 45, 43-52.

Holme, I., Krogstrup, P., Hansen, J. (1997). Embryogenic callus formation, growth and regeneration in callus and suspension cultures of Miscanthus $\times$ ogiformis Honda 'Giganteus' as affected by proline. Plant Cell Tiss. Org. Cult., 50, 203-210.

Kundelchuk, O. P., Tarasenko, L. V., Blume, Ya. B. (2002). Influence of amiprophosmethyl on the root cell structure in the herbicide-sensitive and resistant lines of Nicotiana plumbaginifolia. Russ. J. Plant Physiol., (3), $381-386$

Lewandowski, I. (1997). Micropropagation of Miscanthus $\times$ giganteus. Biotech. Agr. Forest., 39, 241-255.

Melnychuk, O. V., Ozheredov, S. P., Sekan, O. S., Bayer, G. Ya., Shysha, O. M., Yemets, A. I. (2015). Development and application of method for miscanthus in vitro culture establishment. Factors Exp. Evol. Organisms, 17, 209-212 (in Ukrainian).

Melnychuk, O. V., Ozheredov, S. P., Rakhmetov, D. B., Yemets, A. I., Blume, Ya. B. (2016). Screening of nitroanilines for their affinity to miscanthus $\alpha$-tubulin for further in vitro polyploidization of miscanthus species. Factors Exp. Evol. Organisms, 18, 212-216 (in Ukrainian).

Morejohn, L. C., Fosket, D. E. (1991). The biochemistry of compounds with anti-microtubule activity in plant cells. Pharm. Ther., 51, 217-230.

Murashige, T., Skoog, F. (1962). A revised medium for rapid growth and bioassays with tobacco tissue culture. Physiol. Plant., 15, 473-497.

Ozheredov, S. P., Yemets, A. I., Brytsun, V. M., Ozheredova, I. P., Lozynskiy, M. O., Blume, Ya. B. (2009). Screening of new 2,4- and 2,6-dinitroaniline derivates on phytotoxicity and antimitotic activity. Cytol. Genetics, 43 (5), 297-304.

Ozheredov, S. P., Yemets, A. I., Lytvyn, D. I., Brytsun, V. M., Schwartau, V. V., Lozynskiy, M. O., Blume, Ya. B. (2010). New 2,6-dinitroaniline compounds with antimitotic mode of action and their synergistic activity in compositions with graminicides. Cytol. Genetics, 5, 306-312.
Pausheva, Z. P. (1988). Workshop on Plant Cytology [Паушева 3. П. Практикум по цитологии растений]. Agropromizdat, Moscow. 271 pp. (in Russian)

Petersen, K. (1997). Callus induction and plant regeneration in Miscanthus $\times$ ogiformis Honda 'Giganteus' as influenced by benzyladenine. Plant Cell Tiss. Org. Cult., 49, 137-140.

Petersen, K., Hagberg, P., Kristiansen, K. (2002). In vitro chromosome doubling of Miscanthus sinensis. Plant Breed., 121, 445-450.

Petersen, K., Hagberg, P., Kristiansen K. (2003). Colchicine and oryzalin mediated chromosome doubling in different genotypes of Miscanthus sinensis. Plant Cell Tiss. Org. Cult., 73, 137-146.

Plazek, A., Dubert, F., Zur, I., Waligorski, P. (2007). In vitro culture of Miscanthus $\times$ giganteus. Zeszyty Problemowe Postepow Nauk Rolniczych., 523, 175-184.

Plazek, A., Dubert, F. (2010). Improvement of medium for Miscanthus $\times$ giganteus callus induction and plant regeneration. Acta Biol. Cracov. Ser. Bot., 52 (1), $105 \times 110$.

Rayburn, A., Crawford, J., Rayburn, C., Juvik, J. (2009). Genome size of three Miscanthus species. Plant Mol. Biol. Rep., 27, 184-188.

Rhodes, C. A., Green, C. E., Phillips, R. L. (1986). Factors affecting tissue culture initiation from maize tassel. Plant Sci., 46, 225-232.

Robinson, J., Engelborghs, Y. (1982). Tubulin polymerization in dimethyl sulfoxide. J. Biol. Chem., 257 (10), 5367-5371.

Somerville, S., Youngs, H., Tailor, S., Davis, S. C., Long, S. P. (2010) Feedstocks for lignocellulosic biofuels. Science, 329 (5993), 790-792.

Spasevska I., Ayoub A. T., Winter P., Preto J., Wong G. K.-S., Dumontet C., Tuszynski J. A. (2017). Modeling the Colchicum autumnale tubulin and a comparison of its interaction with colchicine to human tubulin. Int. J. Mol. Sci. 1676, 18.

Thomas, H. (1993). Chromosome manipulation and polyploidy. In: Chromosome Manipulation and Polyploidy in Plant Breeding: Principles and Prospects. Hayward, M. D., Bosemark, N. O., Romagosa, T. (eds.). Chapman and Hall, London, pp. 79-92.

Tytko, R., Kalilichenko, V. (2010). Renewable Energy Sources (Poland experience for Ukraine). OWG, Warshaw. 533 pp. (in Ukrainian).

Weijde, T., Alvim Kamei, C. L., Torres, A. F., Vermerris, W., Dolstra, O., Visser, R. G., Trindade, L. M. (2013). The potential of C4 grasses for cellulosic biofuel production. Front. Plant Sci., 4, 107.

Weijde, T., Kiesel, A., Iqbal, Y., Muylle, H., Dolstra, O., Visser, R.G., Lewandowski, I., Trindade, L. M. (2017), Evaluation of Miscanthus sinensis biomass quality as feedstock for conversion into different bioenergy products. GCB Bioenergy, 9, 176-190.

Wan, Y., Ducan, D. R., Rayburn, A. L., Widholm, J. M. (1991). The use of antimicrotubule herbicides for the production of doubled haploid plants from anther culture derived maize callus. Theor. Appl. Genetics., 81, 205-211.

Wang, X., Yamada, T., Kong, F. J., Abe, Y., Hoshino, Y., Sato, H., Takamizo, T., Kanazawa, A., Yamada, T. (2011). Establishment of an efficient in vitro culture and particle bombardment-mediated transformation systems in Miscanthus sinensis Anderss., a potential bioenergy crop. GCB Bioenergy, 3 (4), 322-332.

Yemets, A. I., Blume, Ya. B. (1999). Plant resistance to herbicides with antimicrotubule mode of action: From natural mutants to gene transfer. Russ. J. Plant Physiol., 46 (6), 899-907 (in Russian).

Yemets, A. I., Blume, Ya. B. (1999). Plant resistance to herbicides with antimicrotubule mode of action: From natural mutants to gene transfer [Емец, А. И., Блюм, Я. Б. Устойчивость растений к гербицидам с антимикротрубочковым механизмом действия: от природных мутантов до переноса генов]. Russ. J. Plant Physiol., 46 (6), 899-907 (in Russian). 
Yemets, A. I., Blume, Ya. B. (2008). Progress in plant polyploidization based on antimicrotubular drugs. The Open Horticulture J., 1 (1), 15-20.

Yu, C. Y., Kim, H. S., Burn, A. L., Widholm, J. M., Juvik, J. A. (2009). Chromosome doubling of the bioenergy crop, Miscanthus $\times$ giganteus. GCB Bioenergy, 1, 404-412.

Zhang, Q. X., Sun, Y., Hu, H. K., Chen, B., Hong, C. T., Guo, H. P., Pan, Y. H., Zheng, B. S. (1991). Micropropagation and plant regeneration from

Received 30 January 2019

Accepted in the final form 12 June 2019 embryogenic callus of Miscanthus sinensis. In Vitro Cell Dev. Biol. Plant., 48, 50-57.

Zilbervarg, I. R., Mitrofanova, I. V., Mitrofanova, O. V., Rabotyagov, V. D., Blume, Ya. B. (1997). Using oryzalin and aminophosmethyl obtaining issope and nep polyploid forms in vitro. Cell Biol. Int., 21 (12), 914-915.

Zili, Y., Puhua, Z., Chengcai, C., Xiang, L., Wenzhong, T., Li, W., Shouyun, C., Zuoshun, T. (2004). Establishment of genetic transformation system for Miscanthus sacchariflorus and obtaining of its transgenic plants. High Tech. Lett., 10, 27-31.

\section{POLIPLOİDIJAS INDUCĒŠANA MILZU MISKANTEI (MISCANTHUS × GIGANTEUS GREEF ET DEU.)}

Parādīta vairāku jaunu dinitroanilīnu antimitotiskā aktivitāte, kas ḷauj efektīvi inducēt augu poliploīdiju. Tiem ir zemāks fitotoksicitātes līmenis, salīdzinot ar savienojumiem, kuri tiek tradicionāli izmantoti šim nolūkam. Eksperimentā gaitā iegūtas poliploīdās milzu miskantes līnijas, kuras ir piemērotas audzēšanai atvērtās grunts apstākḷos. 